\title{
How Peircean Semiotic Philosophy Connects Western Science with Eastern Emptiness Ontology
}

\author{
Brier, Søren
}

\author{
Document Version \\ Accepted author manuscript \\ Published in: \\ Progress in Biophysics \& Molecular Biology \\ DOI: \\ 10.1016/j.pbiomolbio.2017.08.011 \\ Publication date: \\ 2017 \\ License \\ CC BY-NC-ND
}

Citation for published version (APA):

Brier, S. (2017). How Peircean Semiotic Philosophy Connects Western Science with Eastern Emptiness Ontology. Progress in Biophysics \& Molecular Biology, 131, 377-386.

https://doi.org/10.1016/j.pbiomolbio.2017.08.011

Link to publication in CBS Research Portal

\section{General rights}

Copyright and moral rights for the publications made accessible in the public portal are retained by the authors and/or other copyright owners and it is a condition of accessing publications that users recognise and abide by the legal requirements associated with these rights.

\section{Take down policy}

If you believe that this document breaches copyright please contact us (research.lib@cbs.dk) providing details, and we will remove access to the work immediately and investigate your claim.

Download date: 26. Apr. 2023

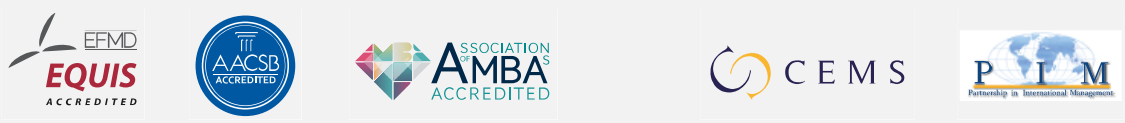




\section{How Peircean Semiotic Philosophy Connects Western Science with Eastern Emptiness Ontology Søren Brier}

Journal article (Accepted manuscript)

CITE: Brier, S. (2017). How Peircean Semiotic Philosophy Connects Western Science with Eastern Emptiness Ontology. Progress in Biophysics \& Molecular Biology, 131, 377-386.

DOI: 10.1016/j.pbiomolbio.2017.08.011 


\section{J. of Progress in Biophysics and Molecular Biology}

\section{How Peircean semiotic philosophy connects Western science with Eastern Emptiness Ontology}

Søren Brier, Department of Management, Society and Communication, Copenhagen Business School ${ }^{1}$.

Abstract: In recent articles in this journal I have discussed why a traditional physicalist and mechanist, as well as an info-computationalist, view of science cannot fulfil the goal of building a transdisciplinary science across Snow's two cultures. There seems to be no path proceeding from mechanistic physicalism to views that encompass phenomenological theories of experiential consciousness and meaning-based cognition and communication. I have suggested, as an alternative, the Cybersemiotic framework's integration of Peirce's semiotics and Luhmann's autopoietic system theory. The present article considers in greater depth the ontological developments necessary to make this possible. It shows how Peirce avoids materialism and German idealism through his building on a concept of emptiness similar to modern quantum field theory, positing an indeterminist objective chance feeding into an evolutionary philosophy of knowing based on pure mathematics and phenomenology that is itself combined with empirically executed fallibilism. Furthermore, he created a new metaphysics in the form of a philosophical synechist triadic process philosophy. This was integrated into the transcendentalist view of process view of science and spirituality developed from Western Unitarianism by Emerson (agapism), and featuring a metaphysics of emptiness and spontaneity (tychism) that are also essential for the Eastern philosophies of Buddhism and Vedanta.

Process philosophy; Peircean Semiotics; Buddhism; quantum philosophy; tychism; synechism;

\section{Introduction ${ }^{2}$}

Natural science is originally based on the stipulated ontology in which the universe is a machine running on, and formed by, abstract universal laws (Brier 2015c). Galileo and Newton's models were constructed before Darwin's theory of evolution and before the Big Bang Cosmogony. The mathematics they used was derived from an absolute universalism, including a reversible time concept. There was no irreversible directionality of time (Prigogine, 1980, 1996 and Prigogine and Stengers 1984). Since irreversible evolution and possible emergence in not possible in this ontology, Descartes (1984[1641]) could only place the qualities of extension (matter) and thinking (mind) in two absolute separate worlds. But the acceptance of biological evolution and later on Big Bang cosmogony, based on an irreversible time process concept, presented us with the problem of how to connect matter and life or how we can explain consciousness from the development of matter and its evolutions in life forms (Kim 1998, Nagel 2012). Furthermore the development of biology in ethology and biosemiotics produced a concept of life conceived as superseding the mechanical view through its experiential qualities (Bekoff, Allen, and Burghardt, 2002, Hoffmeyer 1996 and 2008a). By contrast, classical science developed Neo-Darwinism

\footnotetext{
${ }^{1}$ Sbr.msc@cbs.dk

2 This article is inspired by my earlier work on Peirce's metaphysics (Brier 2008 a, b and c, 2009a , 2014 and 2015)
} 
by way of genetics, probability theory and ecology, but it never solved the core ontological problem of how to progress from matter to sentient beings (Ruse 1996, Nagel 2012, Kim 1998). As Penrose (1997: 97-98) observes, “...we have the challenge of understanding the mental world in terms of the physical world". Penrose himself has spent much of his life as a researcher proving that mind - though it may have computational properties - supersedes the computational in many ways (Penrose 1965).

\section{An ontological bridge between mind and matter compatible with modern science?}

This unsolved problem of the place of experiential mind in modern science is responsible for the many supplementary attempts to envisage the bridge between human consciousness and material nature: for instance from a biological scientific and cybernetic theory of love (Maturana and Verden-Zöller 2008), starting from our daily emotional living in love as a given. Bertallanffy's general systems theory has, with an organismic ontological background, delivered an informationally-based general theory of selforganization (Bertalanffy, 1976/68), further developed in Jantsch (1980). Here the organic world is taken as the given and the challenge is to explain the material as well as the experiential from cybernetic and systemic views of life and mind. As Brier (2008a) argues, both cybernetics and systems theory ultimately fail to deliver an ontological bridge between nature as self-organized matter, governed by information and energy, and our lived experiential world of meaning. The goal has been to facilitate a full scientific worldview that would include the qualitative sciences of experience and meaning that are so foundational to any theory of science and measurement, a fact that is made evident in Peirce's semiotic philosophy (Brier 2008b).

Prigogine and Stengers (1984) theory of dissipative structures offered an acceptable non-mechanistic basis, when it was formulated in Boltzmann's probabilistic thermodynamic science's terms. Furthermore, it was supportive to general system theory's theory of emergence. But it was still based on a materialistic ontology without a phenomenological aspect. Prigogine extended Boltzmann's theory into a nonequilibrium thermodynamics based on an irreversible time concept instead of the mechanistic Lagrangian time-reversible equation. In this way, he changed the ontology of physics from an eternal machine in a reversal timeframe. Thus, Prigogine shifted to a process philosophy based on an irreversible time concept with thermodynamics as fundamental - or even more fundamental - than mechanics in a physicalist world view. Prigogine did not create a full alternative to the ontological postulate of eternal transcendental laws governing the mechanical materialist physicalistic world view; but, in 2013, the famous physicist Lee Smolin wrote the book Time Reborn: From the Crisis in Physics to the Future of the Universe, where he acknowledged Peirce's process philosophy. In particular, he emphasized Peirce's suggestion that physical laws are not eternal but manifest successively in the cosmogony of the universe. John A. Wheeler (1994:300) also embraced such a view when questioning laws in the explanation of existence. One of the benefits of the process view was that it was much more supportive of the biological theory of evolution - which is also a process philosophy based on irreversible time. So, at this point, the ontology of the universe changed from a machine metaphor to a process metaphor, a view which is much more in tune with the Buddhist idea of an ever-changing being. Such a process ontology may well be a proper foundation for any bridge between matter and mind in that it changes the whole ontological status of both. In systems theory, however, there has been no developed concept of individuality since all systems are viewed as open. This, despite the fact that species specific individual agency is very much in the nature of living systems. 


\section{Ontology of individual agency}

Attempts to make progress in this matter were pursued in second order cybernetic theory. Maturana and Varela's cybernetically-inspired theory of autopoiesis (Maturana and Varela 1980 and 1986) changed the terms of discussion conclusively. Here was a cybernetic system theory of closed systems that was not based on open information exchange, but on the concepts of structural couplings, which viewed influence between systems not on the basis of information flow, but from an embodied interactionist viewpoint. The basis was no longer info-computational, as communication did not simply amount to transmissions of objective information counted in bits. Nevertheless, Maturana and Varela formulated no concept of interpretation either; and though they and Gregory Bateson operated with animal cognition as a 'difference that made a difference', they developed no theory connecting the experiential with the material (Brier 2008a). The existence of the experiential mind was just taken for granted; the circular causality was assumed to be enough in order to construct agency (Brier 2008a $+b$ ).

To many scientist these considerations constitute mere metaphysical discussions. Contrary to most research in science as well as philosophy of science (except for Bhaskar 2000), Peirce viewed metaphysics as the reflective attempt to generalize our engagement with the universe. He therefore worked consciously and reflectively with his scientific metaphysics in order to solve these problems. $\mathrm{He}$ wrote:

Find a scientific man who proposes to get along without any metaphysics -- not by any means every man who holds the ordinary reasonings of metaphysicians in scorn -- and you have found one whose doctrines are thoroughly vitiated by the crude and uncriticized metaphysics with which they are packed. We must philosophize, said the great naturalist Aristotle -- if only to avoid philosophizing. Every man of us has a metaphysics, and has to have one; and it will influence his life greatly. Far better, then, that that metaphysics should be criticized and not be allowed to run loose.

(CP 1.129) $)^{3}$.

Peirce realized that it was impossible to entertain a mechanical concept of matter as completely dead, governed only by absolute law, and still be able to proceed to an understanding of life and mind. Evolutionary theory forces us into - what he calls - a synechist ontology, where there must be continuity between what we have worked out to be the "stuff" that the physical, chemical and biological processes were organizing and our experiential psychological and cultural-linguistic domains of lived reality - or what Husserl called out lifeworld.

Peirce saw that he needed a synechistic ontological concept that could support the whole range of matter, life, mind, cognition and communication. Since all ideas and theories we produce in our philosophical and scientific endeavors arise from the level of conscious communication, whatever

\footnotetext{
${ }^{3}$ I uphold the tradition of referring to Peirce's work with the following abbreviations: CP for Collected Papers (see Peirce, C. S. [1931-58]. Collected Papers.); EP for Essential Peirce (see Houser, Nathan \& Christian Kloesel (eds.)(1992). The Essential Peirce. Selected Philosophical Writings, Volume 1 (1867-1893) and Peirce Edition Project (ed.)(1998). The Essential Peirce. Selected, Philosophical Writings, Volume 2 (1893-1913)), W for Writings (see Peirce Edition Project (19822009) Writings of Charles S. Peirce: A Chronological Edition 1857-1892 Volume 1- 8. NEM vol. pages: Carolyn Eisele (ed., 1976), The New Elements of Mathematics by Charles S. Peirce. RLT for Reasoning and the logic of Things. The Cambridge Conferences Lectures of 1898 by Charles Sanders Peirce, Ketner, K.L., Cambridge: Harvard University Press, 1992. MS for unpublished manuscripts that are now often published on websites like for instance Arisbe. MS for unpublished Manuscripts kept in the Houghton Library at Harvard numbers from Richard R. Robin's catalogue.
} 
theories we have of the so-called outer nature $(\mathrm{CP}, 6.540)$, Peirce realized that the answer could not be sought through dualism. Dualism was too limited, too absolute and too lacking in dynamism to support the knowing process as well as the development of the universe and the evolution of the living systems. Peirce saw as his primary task the development of a comprehensive metaphysical and epistemological system, superseding Kant and Hegel; a system that dealt with mind, matter and evolution. Thus he needed another foundation that was neither mind nor matter- a creatio ex nihilo or creation from nothing.

\section{The world emerging from nothing}

The idea of the world emerging from nothing has roots in Christian, Greek and Indian belief systems. For the Indian Advaita Vedantic philosopher, Shankara, the supreme Brahman is Nirakara (formless), Nirvisesha (without attributes) and Akarta (non-agent) (Sankaracharya.org 2017). This view of emergence of the Cosmos can be supported by one of the many translations of the creational hymn from the Rig Veda:

"The non-existent was not; the existent was not then.

The atmosphere was not, the heavens beyond not.

What was hidden? Where? In whose keeping?

Was it water? A bottomless deep?

There was neither death nor immortality then.

There was no distinction of day or night.

What breathed by its own power was breathless.

Other than that, there was nothing else.

Darkness was hidden by darkness at first.

It was all an indistinguishable sea.

The void covered all that which becomes, all to be born through energy of heat alone.

From that, desire arose in the beginning.

This was the first effect of thought.

Having looked into the heart, wise sages

saw this link of nonexistence to existence.

Their line of sight was extended across:

what was below, what was above?

There were impregnators, there were powers:

inherent power below, impulses above.

Who knows really? Who here will say

where it arose, from where this creation came?

The gods came after this creation.

Who, then, knows from where being has come? 
From where has this creation come into being?

Was it made or no made?

He in the highest heaven, its surveyor,

Surely he knows, or maybe not. “”

\section{(http://englishare.net/World\%20Lit/WL1--Lesson11-ReadingA-Veda.htm)}

Worth noticing here is the lack of certainty about first matters of origin and that the deep basic process of impersonalized thinking and desiring seems to be the power of creation. Notice, also, the awareness of how difficult it is to speak of the transcendent and of what happens at the border between the transcendent and the immanent, where form, time and space have not yet become fully manifest.

Peirce, aptly, chooses to go return to the Old Testament concept of Tohu (wa) Bohu, which meant something like: formless empty void chaos. In outlining his cosmogony, at the outset Peirce writes: "The state of things in the infinite past is chaos, tohu bohu, the nothingness of which consists in the total absence of regularity". (CP 8.317). Peirce's suggestion for a new non-mechanical - but realist - ontology was a triadic 'process semiotics' in combination with a fallibilist view of empirical science (Esposito, 1980). As Deely (2001) writes, Peirce may be the first true postmodern scholar and philosopher through his realist dynamic web theory of triadic dynamic sign relations which are resolutely not derived from such concepts as transcendental egos and "things in themselves". Peirce notes:

"For forty years, that is, since the beginning of the year 1867, I have been constantly on the alert to find a genuine triadic relation -- that is, one that does not consist in a mere collocation of dyadic relations, or the negative of such, etc. ... which is not either an intellectual relation or a relation concerned with the less comprehensible phenomena of life...In short, the problem of how genuine triadic relationships first arose in the world is a better, because more definite, formulation of the problem of how life first came about; and no explanation has ever been offered except that of pure chance, which we must suspect to be no explanation, owing to the suspicion that pure chance may itself be a vital phenomenon. In that case, life in the physiological sense would be due to life in the metaphysical sense. ... there is some essentially and irreducibly other element in the universe than pure dynamism .... "(CP 6: 322.)

Peirce's prescience, here, is evident in how he comes close to a modern quantum field physical conception, where "particles" arise as entangled probability processes manifesting an underlying veiled reality in the patterns arising out of measuring processes (d'Espagnat 2006, Wheeler, 1992). A way to interpret Peirce is that quantum particles are potential signs. At the quantum physical level they manifest when the probability wave collapses. At macro level perception this is what happens when Secondness - as irritation of the sense organ in the form of a difference - is interpreted through the process of Thirdness into a sign. Thus, for Peirce, the triadic ontology starts in the experience of qualia (sentiment) and, from there, reaches all the way down into matter. He adds:

"...whatever is First is ipso facto sentient. If I make atoms swerve - as I do - I make them swerve but very very little, because I conceive they are not absolutely dead. And by that I do not mean exactly that I hold them to be physically such as the materialists hold them to be, only with a small dose of 
sentiency superadded. For that, I grant, would be feeble enough. But what I mean is, that all there is, is First, Feelings; Second, Efforts; Third, Habits - all of which are more familiar to us on their psychical side than on their physical side; and that dead matter would be merely the final result of the complete induration of habit reducing the free play of feeling and the brute irrationality of effort to complete death “(CP 6.201)

For those who may think that this deviation from a mechanical view of dead matter is deeply "unscientific", the physicist Bernard d'Espagnat writes in the conclusion of his life work analyzing quantum physics:

Hence the idea that Being is somehow prior to the mind-matter splitting becomes defensible even in front of a scientific audience. Consequently, the idea that mind may vaguely "recall" something of Being does not look any longer irremediably absurd. So that, even though it is not "reachable" the "Being" in question appears to be an "I don't know what" to which it is conceivable that the human mind is not altogether extraneous. A being, in other words, that may constitute for it a horizon. What I mean is that, perhaps, the archetypes of some of our feelings, great longing, love, etc. are hidden there.

(d’Espagnat 2006: 463)

Peirce actually worked with conceptualizing this "I do not know what" in his synechist and tychist triadic philosophy, using Aristotle's hylopathic (CP 1.24) concept of matter dubbed hylozoism. Here matter is viewed as something which, in a very general way, is internally alive. This concept of matter combined with Peirce's synechism corresponds with Aristotle's plenum understanding of matter, which was an alternative to Democritus' atomistic view of reality as built up from or by some absolute smallest and indivisible parts of reality. The Peirce expert M. C. Murphey (1993: 395) explains:

[Peirce] required a property characterizing unactualized possibilities which would be itself actual so that it could be observed. Yet incredibly enough Peirce found such a property in 1896 in continuity. For by his definition of the continuum . . . any true continuum must contain potentialities which are not only not now actualized but which are greater in multitude than any set of events which can ever be actualized.

Thus Democritus' atomistic view of the world as built from indivisible independent things - so important for classical physics and even the concept of 'elementary particle' - is not compatible with modern quantum field theory and its acceptance of entanglement. As d'Espagnat (1989: 158) writes in the introduction to his Scientific American article "Quantum Theory and Reality":

The doctrine that the world is made up of objects whose existence is independent of human consciousness turns out to be in conflict with quantum mechanics and with facts established by experiments.

This fact changes the whole ontological foundation for modern science and may be the opening that we are - and Peirce was - looking for. 


\section{Modern reconceptualization of Peirce's Schelling inspired process ontology}

Thus we are back philosophizing on the connection between our subjectively experienced, but collectively conceptualized, reality and an independent reality. Peirce's contribution was his minddependent triadic process semiotics, where signs have a certain self-organized life of their own based on the introduction of feeling as an ontological element in Firstness. He wrote about his concept of consciousness and the mental that:

“... nothing but feeling is exclusively mental. But while I say this, it must not be inferred that I regard consciousness as a mere "epiphenomenon"; ... consciousness may be defined as that congeries of nonrelative predicates, varying greatly in quality and in intensity, which are symptomatic of the interaction of the outer world, - the world of those causes that are exceedingly compulsive upon the modes of consciousness, with general disturbance sometimes amounting to shock, and are acted upon only slightly, and only by a special kind of effort, muscular effort,- - and of the inner world, apparently derived from the outer, and amenable to direct effort of various kinds with feeble reactions, the interaction of these two worlds chiefly consisting of a direct action of the outer world upon the inner and an indirect action of the inner world upon the outer through the operation of habits."

(EP 2.418-419).

In modern times, also, quantum physicist John Archibald Wheeler (1911- 2008) was very much aware of the deep problem of how to conceptualize the inner-outer interaction in human cognition and action in the ontology behind Western scientific thinking. His "it from bit participatory universe" (Wheeler 1990 and 1992) is - in competition with d'Espagnat (2006) and Stapp (2007) - the closest any modern philosophical physicist has come to Peirce's vision. Wheeler (1990: 5) wrote:

"It from bit symbolizes the idea that every item of the physical world has at bottom - a very deep bottom, in most instances - an immaterial source and explanation; that which we call reality arises in the last analysis from the posing of yes-or-no questions and the registering of equipment-evoked responses; in short, that all things physical are information-theoretic in origin and that this is a participatory universe. “

Wheeler's view is that the universe is an enormous feedback loop. Here we contribute to the ongoing creation of not just the present and the future but the past as well in a delayed-choice experiment-way. Our measurement influences the past. This is not a subjective idealism but rather an interactive instrumentalism, as it is the scientists that are the ones doing these delay choice experiments. Furthermore, he even considers every quantum event as a measurement act that in itself influences the past. Wheeler's view seems to rest on an objective information-theoretical concept based on the bit or what Bateson in a more cybernetic circular causal conception would call a difference that makes a difference and which Peirce has developed in the triadic process sign, where information is encapsulated in the context dependent meaning of a message between sender and receiver (Brier 2015a). But like Bateson, Wheeler in his instrumentalism misses a theory of consciousness with a phenomenological basis and the meaningful lifeworld of Husserl that leads Penrose (1996) to prove that human consciousness and language has capacities beyond computation and makes 
phenomenologically-inspired philosopher Nagel (2012) write the book Mind \& Cosmos: Why the NeoDarwinian Conception of Nature is Almost Certainly False. In basing his view on an objective information-theoretical view Wheeler fails to establish the reflective phenomenological basis that is so foundational to Peirce's pragmaticist semiotics and connective synechism.

It is in my view necessary to create a full philosophy and theory of science as Peirce does. Peirce's philosophy - in my view - supersedes Wheeler's informational view by his alternative semiotic process philosophy of reasoning. Quantum field theory seems ontologically to have arrived at the necessity for a consistent scientific ontology to assume a foundational ur-continuity before the spilt between mind and matter. This seems pretty much what d'Espagnat emphasizes, above. Peirce suggests calling it the void or pure Zero. He wrote.

If we are to proceed in a logical and scientific manner, we must, in order to account for the whole universe, suppose an initial condition in which the whole universe was non-existent, and therefore a state of absolute nothing. ...We start, then, with nothing, pure zero. But this is not the nothing of negation. For not means other than, and other is merely a synonym of the ordinal numeral second. As such it implies a first; while the present pure zero is prior to every first. The nothing of negation is the nothing of death, which comes second to, or after, everything. But this pure zero is the nothing of not having been born. There is no individual thing, no compulsion outward nor inward, no law. It is the germinal nothing, in which the whole universe is involved or foreshadowed. As such, it is absolutely undefined and unlimited possibility - boundless possibility. There is no compulsion and no law. It is boundless freedom. (CP 6.215-217).

This idea of nothingness behind and before Firstness evinced in this quote reveals a deep foundational issue in Peirce's metaphysics. As mentioned, he uses the Old Testament concept of Tohu Bohu, which describes the condition of reality before God said, "Let there be light" (Genesis. 1:3):

"In that state of absolute nullity, in or out of time, that is, before or after the evolution of time, there must then have been a tohu bohu of which nothing whatever affirmative or negative was true universally."

(CP 6.490)

The idea of placing ones ontology, not on matter, or energy or information, but on emptiness is also close to the foundation that the Buddhist-inspired logician George Spencer Brown explores in his book Laws of form (1979) and especially in the footnotes of his pseudonymously authored Only Two Can Play This Game (Spencer Brown 1974). This nothing - which is not the negation of something - is the origin of the universe and all manifest laws of any kind. Thus physics itself rests upon it, as all kinds of knowing rests on this empty being of potentialities. Thus Peirce's synechism has an ontological foundation in the great emptiness from which the three universes of Firstness (qualia and potentialities), Secondness (resistance, particularity, will, and brute force), and Thirdness (mediation and habit-taking) emerge in his evolutionary metaphysics.

It is interesting that this view of emptiness as the source of everything also coincides with Feynman's development of quantum electrodynamics. This is because Feynman is developing physics from a particle view (atomism) into a field ontology (see Feynman 1965, 1988 and a modern use of it in Haisch and Dobyns 2001). This field ontology includes the idea of a vacuum field with virtual particles not 
manifesting as material particles outside the Planck time and space unless they are excited with extra energy. An example today is Hawking's Black hole radiation (non-technically described in Hawking 1988). But what is the impetus for development in an ontology of emptiness commencing from absolutely nothing?

\section{Tychism: The dynamism of real chance}

Inspired by Schelling and Die Naturphilosophie, Peirce introduces tychism into his ontology.

This is the view that chance is real in the sense of the spontaneity and chance from which nature emerges often viewed as the original chaos. Tychastic chance implicates the power of possibility, contingency, and boundless freedom as an originating nothingness that is fundamental to the initial state of Peirce's cosmology, as we can see in this quotation.: "three elements are active in the world: first, chance; second, law; and third, habit-taking" (CP1.409). Peirce shares a propensity theory of chance with the much later Popper (Popper, 1959 and Miller, 1975) and, in the famous article The Law of Mind (CP 6.102) from his Monist series, he launches an evolutionary process view of nature to explain the reality of laws as emerging through evolution. This was the perspective picked up much later, as mentioned, by Smolin (2013).

With his inspiration from Emerson (1884) and the Unitarians (Howe, 1970), Peirce sees no foundational division between their trans-religious concept of the divine (Richardson 1995) and his own fallibilist view of science, as well as religion, in a common synechist search for truth (CP 6. 433). With Schelling, Peirce shares the idea of the divine process of self-realization from will to reason (Schelling 1989/1809, Zöller 2000). Peirce wrote: "I am a Schellingian of some stripe..." (CP, 6.605). Schelling (1989), like Peirce, had also an evolutionary idealistic and a developmental model of nature governed by a triadic model of the categories of nature's being. Schelling furthermore argued that the first mode of possibility - what Peirce calls absolute chance or tychism (CP 6.102) - was a fundamental or transcendental ground necessary also for the cosmos to grow and evolve.

This process philosophy is based on the understanding of nature as a continuum evolving from an unruly potentiality through habit taking toward the development of an absolute mind. Niemoczynski (2011) points to a second common theme found in the philosophy of Peirce and Schelling: the need for a new classification of knowledge in order to give rise to a philosophically sound basis for studying and understanding the cosmos based on a new and broader (transdisciplinary) understanding of science that allows humans to better understand the unfolding of life. Therefore pragmaticism rests on a special integration of mathematics, phenomenology, empirical science, and semiotics. Peirce contrasted materialism (all that exists is matter) and idealism (all that exists is ideas), with his own monistic synechism, emphasizing "the tendency to regard everything as continuous" (CP 7.565). He needed a new and broader metaphysics for its basis than was available in the sciences at that time. Although Peirce acknowledges his philosophy as a kind of objective idealism, I think this peculiar aspect of this philosophy places Peirce in a worldview beyond materialism and idealism, in a non-dualism combined with a triadic, evolutionary pragmatism that Peirce calls pragmaticism. It is a sort of monism; but instead of having to choose between matter and spirit - where Hegel chose spirit - Peirce sides with Buddhism, Advaita Vedanta and quantum physicists ${ }^{4}$ - and chooses a synechistic non-dual plenum.

\footnotetext{
${ }^{4}$ In Schrödinger's probability wave model of quantum mechanics, reality exists as potentials until the quantum wave collapses through the measurement process into a specific physical reality. This understanding is integrated into the Copenhagen model of quantum mechanics, where reality is seen neither as neither a wave nor as a particle, until the moment the token is materialized through the measurement. This is interesting as Peirce's view of signs is that they are dynamical triadic process types that only manifests as tokens.
} 
For Peirce, then, the primordial, originating nothingness is the nothingness that results from freedom and potentiality continually annulling themselves through variety and spontaneity in a non-foundational, transcendental ground, from within which the world evolves. The mediation between the passive and the dynamic spontaneous basis for the cosmic is resolved by Peirce though mediation by Thirdness, which is the tendency to take habits. This is a view well developed in Romanini and Fernándes (2014), but is also present in Peirce's inspiration from Schelling, as Ejsing (2007) points out. Three general features or qualities of rational knowing drive this development, which Stjernfelt (2014) investigate as the development of dicisign.

But if there is no personal Christian god or no Hegelian spirit, then what impels the evolutionary logic? For Peirce, it is Agapism or Evolutionary Love that has been the main direction of his process philosophy through his scientific metaphysical architecture. This is part and parcel, as well as the logic, of his objective idealist realistic philosophy and Synechism, since the evolving process of reasonability through ongoing semiosis is a continuous teleological self-corrective movement toward an unspecified Summon Bonum. For Peirce Agapism refers to the third mode of evolution of the universe - the first being tychasm or rule by chance; the second being anacasm, ruled by necessity (CP 6.302). The third is ruled by abstract or evolutionary love connected to the development of reasonability. This is because it develops the generality of the good and continuity as part of the evolutionary process (CP 5.4). Peirce writes:

I propose to devote a few pages to a very slight examination of these questions in their relation to the historical development of human thought. I first formulate for the reader's convenience the briefest possible definitions of the three conceivable modes of development of thought, distinguishing also two varieties of anancasm and three of agapasm. The tychastic development of thought, then, will consist in slight departures from habitual ideas in different directions indifferently, quite purposeless and quite unconstrained whether by outward circumstances or by force of logic, these new departures being followed by unforeseen results which tend to fix some of them as habits more than others. The anancastic development of thought will consist of new ideas adopted without foreseeing whither they tend, but having a character determined by causes either external to the mind, such as changed circumstances of life, or internal to the mind as logical developments of ideas already accepted, such as generalizations. The agapastic development of thought is the adoption of certain mental tendencies, not altogether heedlessly, as in tychasm, nor quite blindly by the mere force of circumstances or of logic, as in anancasm, but by an immediate attraction for the idea itself, ... by virtue of the continuity of mind.

(CP 6, 307)

\section{Logic is semiotic processual development}

We see Peirce through his inspiration from Emerson and the Concord transcendentalist unites major traditions in Western and Eastern philosophy to establish an ontology that can support a transdisciplinary view of science. It is a panentheistic non-dualism that makes the foundation for his phaneroscopic point of departure, where Peirce viewed his semiotics as an expansion of the limited formal view of logic developed in the West. Logic is semiotics, he says in several places (CP 2.227-231): “... I extend logic 
to embrace all the necessary principles of semeiotic, and I recognize a logic of icons, and a logic of indices, as well as a logic of symbols." (CP 4.9).

Peirce's view of the continuum furthermore offered not only an alternative view of the mathematical continuum, but also provides a possibility of finally advancing beyond Parmenides, as Robertson (2000) argues. This philosophy places emptiness and the void at the center of Peirce's metaphysics, as is the case in Buddhism. It is central to Mahayana Buddhism that is pursues a knowledge of a non-verbal reality where there are neither things, concepts nor events; a basic unity among the multiplicity of all realization that all events, things and words are deeply connected that they actually constitutes a single event; the body of being or Dharmakaya (Suzuki 1963). It is a silent emptiness beyond words, an unspeakable suchness, which is also central to Zen Buddhism (Suzuki 1969). In the version of Buddhism represented in the writings of the philosopher Nargajuna's famous explanation of the middle way, "Whatever is dependently co-arising. That is explained to be emptiness. That, being a dependent designation, is itself the middle way "(Nargajuna \& Garfield 1995: 93). All events in the past, the present and the future are interdependent like in quantum Field theory. "all phenomena come into being in dependence upon conditions, remain in existence dependent upon conditions, and cease to exist dependent upon conditions"(Nargajuna \& Garfield, 199:160). “"Whatever is dependent co-arisen[.] That is explained to be emptiness. That, being a dependent designation, Is itself the middle way. [...] 19. Something that is not dependently arisen, Such a thing does not exist. Therefore, a nonempty thing does not exist. [...] 36. If dependent arising is denied, Emptiness itself is rejected. This would contradict all of the worldly conventions.." (Nargajuna \& Garfield, 1995: 304-13).

Nargajuna further argues: "All phenomena are arisen, but arise as empty, and as dependent. [...] arising, abiding, and ceasing are not entities at all-they are mere relations... " (Nargajuna \& Garfield, 1995:169). Dynamic triadic relation and rational meaningful processes are the core of Peircean semiotics. This is the issue also surveyed by Merrell (2009). Nargajuna's verse defines the middle way of Buddhism, based on the view that everything is supported and connected by a positive emptiness in the form of a primary being - a view we also saw offered by d'Espagnat. This idea is the foundation for nearly all major Buddhist schools in East Asia (Garfield 1995). The metaphysics of emptiness is to be found not only in Buddhism but also in the Vedic thinking of Shankara's Aidvaita Vedanta (Isayeva 1993, Hartshorne and Reese, 1953). Peirce saw in this notion a connection to his synechism, evident in the following quotation on the problem of establishing a theory of the self:

There is still another direction in which the barbaric conception of personal identity must be broadened. A Brahmanical hymn begins as follows: "I am that pure and infinite Self, who am bliss, eternal, manifest, all-pervading, and who am the substrate of all that owns name and form". This expresses more than humiliation, - the utter swallowing up of the poor individual self in the Spirit of prayer. All communication from mind to mind is through continuity of being. A man is capable of having assigned to him a rôle in the drama of creation, and so far as he loses himself in that rôle, - no matter how humble it may be - so identifies himself with its Author.

(CP 7.572).

Thus, it is not surprising that Peirce sees a deep connection between Christianity and Buddhism. Inspired by the transcendentalists, he envisages Buddhism and Christianity melting together within a transcendental religious view of empathy and love as the foundation of human reality. This is not a 
traditional theistic religion with a personal creator god, but rather a form of mystical Gnosticism - as Bloom (1992 and 1996) so vividly describes in his analysis of American religion - but without a minor creator god responsible for the imperfections of the world as is so typical for the gnostic view of manifest reality as bad. In Peirce's late writings one can pick out the following passage to support this view:

Pragmaticism, then, is a theory of logical analysis, or true definition; and its merits are greatest in its application to the highest metaphysical conceptions. . . . A full exposition of the pragmaticistic definition of Ens necessarium would require many pages; ... That perfect cosmology must therefore show that the whole history of the three universes, as it has been and is to be, would follow from a premiss which would not suppose them to exist at all. Moreover, such premiss must in actual fact be true. But that premiss must represent a state of things in which the three universes were completely nil. Consequently, whether in time or not, the three universes must actually be absolutely necessary results of a state of utter nothingness.

(CP 6.490).

Peirce sees the world as divided into two dimensions: the invisible, unified, unmanifest, implicit, synechist level of reality (the void); and the visible, manifold, manifest, explicit, creative process of reality through habits developing in irreversible time. As a unity, this divine unity is the transcendental - immanence; the one unchanging spiritual ground of all created things:

I may mention that my chief avocation in the last ten years has been to develop my cosmology. This theory is that the evolution of the world is hyperbolic, that is, proceeds from one state of things in the infinite past, to a different state of things in the infinite future. The state of things in the infinite past is a chaotic emptiness, tohu bohu, the nothingness of which consists in the total absence of regularity. ... I believe the law of habit to be purely psychical. But then I suppose matter is merely mind deadened by the development of habit. While every physical process can be reversed without violation of the law of mechanics, the law of habit forbids such reversal.

(CP 8.317-318).

Like the Buddhists, Peirce conceives of this order as no-thing. Niemoczynsky (2011) shows that both Eckhart and Böhme posited a pre-personal ground within God's own being, where this ground was called "the godhead" or "the abyss". It contains infinite potential, the absolute freedom to be, and even the will or desire to be. The Logos in Peirce's pragmaticism is what he calls logic as semiotics and emerges as thirdness or the tendency to take habits in all nature of Secondness and feeling as present in all matter (Hylozoism). All three categories arise as universes from pure Zero. Wheeler (1992: 300) is on the same track when he writes of "Existence" thus built on "insubstantial nothingness".

It is clear that the concept of god in panentheism is not a personal god, but a transcendent creative principle at the center of reality, "before" and "outside" time that from, a pure zero of nothingness - called by Peirce the tendency of taking habits (CP 1.409) - sets off the self-organizing capability of the work of the emerging universe. The existential question of the relation between this principle and human consciousness is not really dealt with at length in Peirce's writings; but Peirce does sum up his view on logic, the reasoning capacity in the universe, and the integration with the 
divine "Chance, love and logic" in the following way: To believe in a god at all, is not that to believe that man's reason is allied to the originating principle of the universe? (CP 2.23-24).

Inspired by Buddhism and transcendental Christianity, Peirce suggests that the universe is the immanent part of the divine and that the other "part" is a transcendental emptiness (Tohu wa Bohu) "behind and before" the manifest world. The transcendental part of the divine is not conscious, but obtains consciousness through creating the manifest world in time, space and energy (Secondness) as well as laws and signification (Thirdness). In Peirce's metaphysics the tool of creation is an ever ongoing evolution.

Actually, Peirce thought that mystical Buddhism was in some ways more profound than Christianity (see Brent 1998: 261and 314). In a letter to William James, Peirce wrote: I can't help thinking that the mother of Christianity, Buddhism, is superior to our own religion. That is what one of my selves, my intellectual self says. (NEM III/2: 872). Peirce and William James were both influenced by Buddhist and Vedic thinking. James met with the first Aidvaita Vedanta philosopher visiting the US from India, Swami Vivekananda (Fredrick 2012). Peirce suggested a general Buddhisto-Christian idea of spirituality, which Peirce, from his Unitarian and semiotic perspective called science and religion, supplements each other in the search for truth and rationality.

[T] he supreme commandment of the Buddhisto-Christian religion is, to generalize, to complete the whole system even until continuity results and the distinct individuals weld together. Thus it is, that while reasoning and the science of reasoning strenuously proclaim the subordination of reasoning to sentiment, the very supreme commandment of sentiment is that man should generalize, or what the logic of relatives shows to be the same thing, should become welded into the universal continuum, which is what true reasoning consists in.

(CP 1.673).

Peirce was trained as a chemist, but worked as a logician and a natural scientist. He was, as mentioned above, influenced by Unitarianism's aim of using science as well as theology in a harmonic way in the search for a naturalist ethics. Peirce's conception of God, which he holds in common with numerous other nineteenth century "Liberal Unitarians", is different from most other Christian movements' conceptions. The early Unitarianism from the Salem and Boston of the 18th and 19th century involved an attempt to reconceive the notion of "God" as compatible with enlightenment through science (Howe 1970).

Thus, a worldview constituted by harmony between ethics, logic, evolution, and spirituality emerged before Peirce was born. This idea of an inner connection between human consciousness and nature is an important way of explaining how it is possible that man can know anything about the world or about Kant's "Ding an sich". Peirce rejected Kant's "Das Ding an sich" as a final limit to the possibility of human knowing. He could not see any reason for limiting our possibility for obtaining knowledge about anything and he considered the world as perfused with signs, as well as believing that all cognition and thinking works through signs. He wrote:

Kant (whom I more than admire) is nothing but a somewhat confused pragmatist. A real is anything that is not affected by men's cognitions about it;... An external object is anything that is not affected by any cognitions, whether about it or not, of the man to whom it is external. Exaggerate this, in the usual philosopher fashion, and you have the conception of what is not affected by any cognitions at all. Take the converse of this definition and you have the notion of what does not affect cognition, and in this 
indirect manner you get a hypostatically abstract notion of what the Ding an sich would be. In this sense, we also have a notion of a sky-blue demonstration; ... The Ding an sich, however, can neither be indicated nor found. Consequently, no proposition can refer to it, and nothing true or false can be predicated of it.

$(\mathrm{CP}, 5.525)$

Here, he departs from modern analytical philosophy in that he does not see logic as a part of language. Rather, he views language as one special way of processing logic and semiotics. Logic and semiotics can (and should) be studied generically, separated from the way they are realized in any particular physical medium (such as a human brain), so that we do not confuse qualities of the medium with qualities of the process. Peirce also departs from Bateson and modern info-computationalism in his concept of information, reminiscent of Nargajuna's and quantum field physics perspective the interdependence of all things Peirce points to the fact that both a sign and its object can harbour any degree of complexity, even to the extent of the complexity of the Universe itself. The kind of sign that is complete enough to convey information is traditionally called a proposition. A verbal proposition is a symbol, and pieces of it (such as words) are traditionally also called "symbols." Such a sign conveys information by combining an indexical sign with an iconic one, and it is the combination of those two functions, rather than the symbolic function per se, that enables the sign to convey information about its object to its interpretant. Peirce defines information as the logical product of 'breadth' and 'depth':

there is one thing which any sign, external or internal, stands for, and another thing which it signifies; its denoted breadth, its 'connoted' depth. They have further generally held, in regard to the most important signs, that the depth, or signification, is intrinsic, the breadth extrinsic (CP 8.119).

Information increases when the breadth is increased, when we learn that a known form actually applies to an object that we did not already know it applied to. Information also increases when depth is increased, when the form applied to a known object is specified or determined more fully than it was before. A sign must have some breadth and depth in order to represent a fact. As Peirce wrote:

What we call a "fact" is something having the structure of a proposition, but supposed to be an element of the very universe itself. The purpose of every sign is to express "fact," and by being joined with other signs, to approach as nearly as possible to determining an interpretant which would be the perfect Truth, the absolute Truth, and as such (at least, we may use this language) would be the very Universe. (EP2:304; see further explanations and arguments in Brier 2015c).

Amidst this extraordinary interdisciplinary background, including phenomenology, Peirce created a transdisciplinary process-philosophy framework for a new fallibilist understanding of the methods of science. This included not only a new scientific cosmogony, but also an existential philosophy drawing on a trans-religious view of the relation between the development of man, science, the meaning of life and the cosmos, all influenced by the new development of symbolic logic (Lewis 1918/60) and the philosophy of Schelling (Ejsing 2007, Brent, 1998, Niemoczynski, 2011). His view is that science and religion are both fallible and always developing. In this way, both religious and scientific fundamentalism is avoided and a transdisciplinary framework for knowledge is created. Peirce's theory 
is not only transdisciplinary but also transcultural, as in Nicolescu's (2002 and 2014) formulation of the term. Peirce delivers a unique cultural paradigm for a trans-scientific enlightenment in a global culture by way of his pragmaticist triadic semiotic philosophy and through the creation of a philosophical framework where a mutual enrichment between science and spirituality will be possible in the future. If Kant is the foundation for modernism in philosophy, Peirce's philosophy is the foundation for a realist cosmodern philosophy of science (Nicolescu 2014), including a science of consciousness.

\section{Conclusion}

From his early interest in the Concord transcendentalist transcultural spiritual studies, Peirce chooses the integration of Buddhism and mystical Christianity - as they are united by the non-personal view of the divine - for the possibilities it harbors as a bridge between science and general spirituality as Emerson also saw it in his integrational view of Eastern and Western cultures' metaphysics. Viewing science as well as the spiritual forms of the search for truth as all being mutually incomplete and fallibilist, Peirce considers them to be complementary and interdependent. This makes it possible to maintain the pragmaticist search for truth and meaning, in respect of his Buddhisto-Christian metaphysics, as well as for science as he understands it.

It is his combination of empirical methods plus the views of logic as semiotic based on a Tychist, synechist and agapist ontology that allows biosemiotics to encompass a biological theory of love - as Maturana projected it - without abandoning scientific foundations. This project is already glimpsed in the reinterpretation of Darwin by David Loye (2003 and 2007), a major project to reintegrate Darwin's theory of love with the foundation of modern evolutionary biology Loye and other researchers from the General Evolution Research Group, informed by general systems theory, are developing an understanding of the role of love in Darwin's work that is very close to Peirce's theory of evolutionary love.

Modern science is very much influenced by the Greek concept of Episteme and the idea of a divine Logos or Nus running through and uniting mind and matter, human consciousness and nature. In modern science the Logos has become formal logic for the mind in absolute time (Brier 2017). With the new development of a computational ontology, the universal laws of nature in physics and their unification are now seen as produced by the new algorithmic intelligence of super computers. The deep problem with this theory is that it does not solve the question of the emergence of experiential conscious beings on Earth and it does not have a theory of experience and meaning as is posited, for instance, in the work of Hans Georg Gadamer.

Peirce's naturalization encompassed pure Zero as the transcendental part of nature and thereby also of us. We are not only connected by matter. The genius of Peirce is that he sees the Logos as semiotics, making the emergence of rational feeling mind possible as thirdness or the tendency to take habits in all nature. This is a general sort of reasoning, as Stjernfelt (2014) argues. If, furthermore, general abstract feeling is present in all matter (Hylozoism) and all three categories arise as universes from pure Zero, why should feeling's self-organization not lead to consciousness being born in every human as realizations in the flesh of the origin of our being?

What fascinates me about this interpretation is that it changes the ontological conception of the theologico-philosophical foundation of reality from the personal creator used in all theism to a general process ontology that is compatible with a semiotically informed science of which biosemiotics is one (Brier 2015b). At the same time, it integrates the "normative" sciences, building on phenomenology 
(and hermeneutics) with the quantitative and empirical sciences to provide a sort of non-reductive view of all the sciences that does not fundamentally oppose a spiritual world view as I have attempted to show in Brier (2008a). Thus, the perspective on which I have commented here allows a dialogue between science and spirituality, Eastern and Western philosophy, in precisely the way that Nicolescu (2002) sees it in his Transdisciplinary manifesto and in his view of human development in From Modernity to Cosmodernity (Nicolescu 2014).

This process philosophy, along with the recognition that the machine metaphor is not a fitting model ontology for science after the quantum revolution (Wheeler 1992), has freed scientific rationality from its enslavement to machines and, especially, the computer (Brier, 2014b). An info-computational ontology therefore cannot be based on the Turing model of computation (Dodig-Crnkovic and Müller 2011), but should rather be based on Peirce's logic as semiotics and his cosmogonical view of nature as a thinking process in continuous development and, among other things, by various forms of evolution of living systems. I think that Peirce and Wheeler would agree on the point that we, as the last link in Cosmos' great development of reasoning, have the power - through science as well as sentiment - to make our own cultures behave in a way that does not prevent the development of more advanced reasoning systems.

\section{References}

Bekoff, M., Allen, C. and Burghardt, G. M. (2002). The Cognitive Animal: Empirical and Theoretical Perspectives on Animal Cognition. Cambridge, MA: MIT Press

Boler, J. F. (1963). Charles Peirce and scholastic realism. Seattle, WA: University of Washington Press.

Bertalanffy 1976 is here: Bertalanffy, L. von (1976/68) General System Theory. Foundations, Development, Applications, New York: BrazillerBhaskar, R.A. (2000). From East to West: Odyssey of a soul. London: Routledge.

Bloom, H. (1992). American religion: The emergence of the Post-Christian nation, New York: Simon \& Schuster.

Bloom, H. (1996). Omens of Millennium: The Gnosis of Angels, Dreams and Resurrection, New York: Riverhead Books.

Brent, J., (1998). Charles Sanders Peirce: A life (Rev. Ed.). Bloomington: Indiana University Press.

Brier, S. (2002/2003): "Luhmann Semiotized", Journal of Sociocybernetics, Vol. 3, No. 2, 2002/2003, pp. 13-22. http://www.unizar.es/sociocybernetics/Journal/dentro.html.

Brier, S. (2008a). Cybersemiotics: Why Information is not Enough, Toronto: Toronto University Press.

Brier, S. (2008b): "Bateson and Peirce on the pattern that connects and the sacred", Chapter 12: 229-255 in Hoffmeyer, J. (ed.)(2008): A Legacy for Living Systems: Gregory Bateson as a precursor for biosemiotic thinking, Biosemiotics 2, London: Springer Verlag. 
Brier, S. (2008c). A Peircean Panentheist Scientific Mysticism. International Journal of Transpersonal Studies; vol. 27, p. 20-45

http://www.transpersonalstudies.org/ImagesRepository/ijts/Downloads/A\%20Peircean\%20Panentheist $\% 2$ 0Scientific\%20Mysticism.pdf

Brier, S. (2009a).'The Conflict between Indian Vedic Mentality and Western Modernity", Durst-Andersen and Lange, E.E. (Ed.)(2010). Mentality and Thought: North, South, East and West, Copenhagen Business School Press, Copenhagen. Pp. 53-86.

Brier, S. (2009b). Cybersemiotic pragmaticism and constructivism. Constructivist Foundations, 5 (1), 1938. Retrieved 26. March 2013 from http://www.univie.ac.at/constructivism/journal/articles/5/1/019.brier.pdf

Brier, S. (2014a). Pure Zero, in Thellefsen, T. and Sørensen, B.(2014): Charles Sanders Peirce in His Own Words: 100 Years of Semiotics, Series: Semiotics, Communication and Cognition [SCC] 14. Berlin, New York: De Gruyter Mouton, pp. 207-12.

Brier, S. (2014b). Nature and Machine, page(s): 127-130. Ethics, Science, Technology, and Engineering : A Global Resource Ed. J. Britt Holbrook. Vol. 4. 2nd ed. Farmington Hills, MI: Macmillan Reference USA.

Brier, Søren (2015a). Can Biosemiotics be a "Science" if its Purpose is to be a Bridge between the Natural, Social and Human Sciences? Progress in Biophysics \& Molecular Biology, Vol. 119, No. 3, 2015, p. 576587.

Brier, S. (2015b). Cybersemiotics and the reasoning powers of the universe: philosophy of information in a semiotic-systemic transdisciplinary approach, Green Letters, Studies in Ecocriticism. Volume 19, Issue 3, 2015,Pp: 280-292: http://www.tandfonline.com/doi/full/10.1080/14688417.2015.1070684.

Brier, S. (2015c). Finding an Information Concept Suited for a Universal Theory of Information. Progress in Biophysics \& Molecular Biology, 119(3), 622-633.

Brier, S. (2016). Pragmaticism, Science and Theology. In: Chinese Semiotic Studies, Vol. 12, Nr. 3, 2016 , p. 473-479.

Brier, S. (2017). Tvaervidenskabsteori, Frederiksberg: Samfundslitteratur.

Carnap, R. (1967). The Logical Structure of the World \& Pseudoproblems in Philosophy, Berkeley and Los Angeles: University of California Press.

Cohen, M. R. (Ed.). (1923). Chance, love and logic: Philosophical essays by the late Charles S. Peirce. London: Kegan Paul, Trench, Trubner \& Co., Ltd. 
Corrington, R. S. (1994). Ecstatic naturalism: Sign of the world. Bloomington, IN: Indiana University Press.

Culp, J. (2013). Panentheism, Stanford Encyclopedia of Philosophy, https://plato.stanford.edu/entries/panentheism/ viewed 08-04-2017

Deely, J. (2001). Four Ages of understanding. The first postmodern survey of philosophy from ancient times to the turn of the Twenty-first century. Toronto: University of Toronto Press 2001.

DeMarco, J. (1972). God, religion, and community in the philosophy of C. S. Peirce. The Modern Schoolman, XLIX, (May), 331-347.

Descartes, R. (1984[1641[) .Meditations on First Philosophy, The philosophical writings of Descartes, Vols. II. 3-62 (J Cottingham, R. Stoothoff, \& D. Murdoch, Eds.). Cambridge: Cambridge University Press.

Dodig-Crnkovic, G. \& Burgin, M. (Eds.)(2011). Information and Computation, Singapore: World Scientific Publishing Co.

Dodig-Crnkovic G. and Müller V. (2011), A Dialogue Concerning Two World Systems: InfoComputational vs. Mechanistic. Book chapter in: Information and Computation, Singapore: World Scientific Publishing Co. Series in Information Studies. Editors: G Dodig-Crnkovic and M Burgin, 2013

Emmerson, R. W. (1883). Works of Ralph Waldo Emmerson, London: George Routledge and Sons.

Ejsing, A. (2007). Theology of anticipation: A constructive study of C. S. Peirce, Princeton theological monograph series: 66. Eugene, OR: Wipf and Stock Publishers.

d'Espagnat, B. (1989). The Quantum Theory and Reality, Scientific American, Now 1989, P. 158-164. https://www.scientificamerican.com/media/pdf/197911_0158.pdf viewed 15'Th of February 2017.

d'Espagnat, B. (2006). On Physics and Philosophy, Princeton: Princeton University Press.

Jantsch, E (1980): The Self-Organizing Universe. New York: Pergamon Pres.

Esposito, J. J. (1980). Evolutionary Metaphysics: The development of Peirce's Theory of Categories, Athens: Ohio University Press.

Feynman, R.P. (1965). The Development of the Space-Time View of Quantum Electrodynamics, Nobel Lecture, December 11, 1965: http://www.nobelprize.org/nobel_prizes/physics/laureates/1965/feynmanlecture.html Viewed 08-04-2017.

Feynman, R.P. (1988). QED: The Strange Theory of Light and Matter, Boston: Princeton University Press. Formann, R.K.C. (2010). Enlightenment is not all it is Cracked up to be, Winchester, UK: O-Books. 
Frederick, N. (2012). William James and Swami Vivekananda: Religious Experience and Vedanta/Yoga in America, William James Studies, 2012, Vol. 9, pp. 37-55 journal.wjsociety.org/wpcontent/uploads/2014/03/frederick.pdf

Visited 08-04-2017.

Garfield, J. L (1995).The Fundamental Wisdom of the Middle Way, Oxford: Oxford university press

Gregersen, N. H. (2004). "Three Varieties of Panentheism", in In Whom We Live and Move and Have Our Being: Panentheistic Reflections on God's Presence in a Scientific World, P. Clayton and A. Peacocke (eds.)(2004), Grand Rapids, MI: William B. Eerdmans.

Haack, S. (1992). Extreme Scholastic Realism: Its Relevance to Philosophy of Science Today, Transactions of the Charles S. Peirce Society, Vol. XXVIII, No. 1 (Winter, 1992), pp. 22-23.)

Haisch, B., Rueda, A. and, Dobyns, Y. (2001). Inertial mass and the quantum vacuum fields, Ann. Phys. (Leipzig), 10, (2001) 5, 393-414.

Hartshorne, C. (1984). Towards a Buddhisto-Christian religion. In K. K. Inada \& N. P. Jacobson (Eds.), Buddhism and American thinkers (pp. 1-13). Albany, NY: State University of New York Press.

Hartshorne, Charles and Reese, William L. (1953)(Eds.), Philosophers Speak of God, Chicago: University of Chicago Press. Reprint in 2000

Hoffmeyer, J. (1996). Signs of Meaning in the Universe, trans. Haveland, B. J., Indiana University Press, Bloomington, IN.

Hawking, S. (1988).A Brief History of Time, New York: Bantam Dell Publishing Group.

Hoffmeyer, J. (2008a). Biosemiotics: An Examination into the Signs of Life and the Life of Signs. University of Scranton Press, Scranton, PA.

Howe, D. W. (1970). The Unitarian Conscience: Harvard Moral Philosophy 1805-1861, Cambridge Massachusetts: Harvard University Press.

Isayeva N. (1993). Shankara and Indian philosophy. Delhi: Sri Satguru Publications.

Kant, I. (1990). Critique of pure reason (J. M. D. Meiklejohn, Trans.). Buffalo, NY: Prometheus Books. (Originally published in 1781)

Kim, J. (1998). Mind in a Physical World: An Essay on the Mind-Body Problem and Mental Causation, Cambridge, Massachusetts: The MIT Press.

McKinnon, A. 1993 „Kierkegaard and the ,Leap of Faith““ Kierkegaardiana 16, Copenhagen, 107-125. 
Kultgen, J. K. (1959-1960). The "future metaphysics" of Peirce and Whitehead. Kant-Studien, 5, 285-293.

Lewis, C. L. (1918/60). A Survey of symbolic logic: The classic algebra of logic, New York: Dover (1960 reprint).

Loye, D. (Ed.)(2003) The Great Adventure: Towards A Fully Human Theory Of Evolution. Albany: State University of New press.

Loye, D. (2007). Darwin's Lost Theory, Philadelphia: Benjamin Franklin Press

Maturana Romesin, H. and Verden-Zöller, G. (2008).The Origin of Humanness in the Biology of Love, Exeter: Imprint Academic.

Maturana, H \& Varela, F. (1980). Autopoiesis and Cognition: The realization of the Living, Reidel, London.

Maturana, H \& Varela, F. (1986): Tree of knowledge: Biological Roots of Human Understanding, Shambhala Publishers. London.

merrel, f. (2009). Musement, play, creativity: Nature's way. Cybernetics \& Human Knowing, 16 (3/4), pp. 89-106

Miller, R. W. (1975). "Propensity: Popper or Peirce?". British Journal for the Philosophy of Science. 26 (2): $123-132$.

Murphey, M. G. (1961). The Development of Peirce's Philosophy, Cambridge, MA: Harvard University Press.

Nagel, T. (2012). Mind \& Cosmos: Why the Neo-Darwinian Conception of Nature is almost certainly False, Oxford: Oxford University Press.

Nicolescu, B. (2002). Manifesto of transdisciplinarity (Karen-Claire Voss, Trans.). Albany, NY: State University of New York (SUNY) Press.

Nicolescu, B. (2014). From Modernity to Cosmodernity: Science, Culture and Spirituality, Albany: State University of New York Press.

Niemoczynski, L. J. (2011). The sacred depths of nature. An ontology of the possible in the philosophy of Peirce and Heidegger. Lanham, MD: Lexington Books. Retrieved March 7, 2013 from http://www.users.drew.edu/rcorring/downloads/SacredDepthsFinalCopy5_09.pdf

Peirce, C. S. (1931-58). Collected papers. (C. Hartshorne \& P. Weiss, Eds.). Cambridge, MA: Harvard University Press. 8 vols. [Past Masters CD-ROM version] 
Peirce, C. S. (1893). Evolutionary love. The Monist, III (2), 176-200.

Houser, Nathan \& Christian Kloesel (eds.)(1992). The Essential Peirce. Selected Philosophical Writings, Volume 1 (1867-1893). Bloomington: Indiana University Press

Peirce Edition Project (ed.)(1998).The Essential Peirce. Selected Philosophical Writings, Vol. 2 (18931913). Bloomington: Indiana University Press.

Penrose, R. (1995): Shadows of the Mind: A Search for the Missing Science of Consciousness, London: Oxford University Press.

Penrose, R. (1987). The Large, the Small and the Human Mind, Cambridge KU: Cambridge University Press.

Popper, K. R. (1959). The Propensity Interpretation of Probability. The British Journal for the Philosophy of Science, Vol. 10, No. 37, (May, 1959), pp. 25-42.

Prigogine, I. (1980): From Being to Becoming, San Francisco: W.H. Freeman.

Prigogine, I. (1996): The End of Certainty. Time, Chaos, and the New Laws of Nature. New York: The Free Press.

Prigogine, I. and Stengers, I. (1984). Order Out of Chaos: Man's New Dialogue with Nature, New York: Bantam Books.

Raposa, M. (1989). Peirce's philosophy of religion: Peirce Studies: Vol. 5. IN: Indiana University Press.

Richardson, R. D. (1995), Emerson: The Mind on Fire, Berkeley: University of California Press

Robertson, R. (2001). "One, two, three . . continuity: C.S. Peirce and the nature of the continuum", Cybernetics \& Human Knowing, Volume 8, Numbers 1-2, pp. 7-24(18).

Romanini, V. and Fernándes E. (2014). Peirce and Biosemiotics, New York: Springer

Ruse, M. (1996). Monad to Man: The Concept of Progress in Evolutionary Biology, Cambridge Massachusetts: Harvard University Press.

Sharma, C. (2009). A critical survey of Indian philosophy. Delhi: Motilal Banarsidass Publishers.

Shankara (2017) http://www.sankaracharya.org/biography_of_sankara.php, seen 07-05-2017.

Shelling, F.W.J. (1989/1809). Philosophical Inquiries into the Nature of Human Freedom, La Salle, Illinois: Open Court.

Smith, V. E. (1950). The idea-men of today, Milwaukee: The Bruce Publishing Company 
Smolin, L. (2014). Time Reborn: From the Crisis in Physics to the Future of the Universe, New York:

Mariner Books

Spencer Brown, G. (under pseudonym James Keys) (1974). Only Two Can Play This Game, New

York: Crown Publishers

Spencer Brown, G. (1979) Laws of Form, 1979. New York: E.P. Dutton.

Stenmark, M. (2004). How to Relate Science and Religion: A Multidimensional Model, Rapids, Michigan: William B. Eerdmans Publishing Company.

Stapp 2007 is here: Stapp, H. P. (2007).The Mindful Universe: Quantum Mechanics and the Participant Observer, Berlin: Springer.

Stjernfelt, F. (2014). Natural Propositions: The Actuality of Peirce's Doctrine of Dicisigns. Boston : Docent Press.

Suzuki, D.T. (1963). Outlines of Mahayana Buddhism by D.T. Suzuki introduced by Alan Watts, New York: Schocken Books.

Suzuki, D.T. (1967). An Introduction to Zen Buddhism, London: Rider \& Co.

Wheeler, J.A. (1990). "Information, physics, Quantum: The search for links”, pp. 3-29 in W.H. Zurek (Ed.). Complexity, entropy and the physics of information. Vol. VIII in Santa Fe Institute, Studies in the Sciences of complexity. Addison Wesley publishing Company.

Wheeler J.A. (1994). At Home in the Universe, Woodbury: AIP Press.

Wheeler, J.A. and Ford, K. (1998). Geons, Black Holes, and Quantum Foam, New York. W.W. Norton Company.

Whitehead, A. N. (1929). Process and reality. New York: Macmillan.

Zöller, G. (2000). German realism: The self-limitation of idealist thinking in Fichte, Schelling and Schopenhauer. p. 209-218 in K. Ameriks (Ed.). The Cambridge companion to German idealism, Cambridge: Cambridge University Press. 